Article

\title{
Ferrocene-Labelled Electroactive Aptamer-Based Sensors (Aptasensors) for Glycated Haemoglobin
}

\author{
Xue-Qing Feng ${ }^{1,2,+}$, Yi Ju ${ }^{1,2,+}$, Wei-Tao Dou ${ }^{3, * \mathbb{D}}$, Qing Li $^{2}$, Zhong-Gan Jin ${ }^{2}$, Xiao-Peng He ${ }^{3}$, Tony D. James ${ }^{4,5, *(\mathbb{D})}$ \\ and Bang-Ce Ye ${ }^{1, * \mathbb{D}}$
}

check for

updates

Citation: Feng, X.-Q.; Ju, Y.; Dou, W.-T.; Li, Q.; Jin, Z.-G.; He, X.-P.; James, T.D.; Ye, B.-C. FerroceneLabelled Electroactive AptamerBased Sensors (Aptasensors) for Glycated Haemoglobin. Molecules 2021, 26, 7077. https://doi.org/ $10.3390 /$ molecules 26237077

Academic Editor: Michail N. Elinson

Received: 16 October 2021

Accepted: 19 November 2021

Published: 23 November 2021

Publisher's Note: MDPI stays neutral with regard to jurisdictional claims in published maps and institutional affiliations.

Copyright: (c) 2021 by the authors. Licensee MDPI, Basel, Switzerland. This article is an open access article distributed under the terms and conditions of the Creative Commons Attribution (CC BY) license (https:/ / creativecommons.org/licenses/by/ $4.0 /)$.
1 Laboratory of Biosystem and Microanalysis, State Key Laboratory of Bioreactor Engineering, East China University of Science and Technology, Shanghai 200237, China; fengxueqing@sccl.org.cn (X.-Q.F.); juyi@sccl.org.cn (Y.J.)

2 Shanghai Center for Clinical Laboratory, Shanghai 200237, China; liqing@sccl.org.cn (Q.L.); jinzhonggan@sccl.org.cn (Z.-G.J.)

3 Key Laboratory for Advanced Materials and Joint International Research Laboratory of Precision Chemistry and Molecular Engineering, Feringa Nobel Prize Scientist Joint Research Center, Frontiers Center for Materiobiology and Dynamic Chemistry, School of Chemistry and Molecular Engineering, East China University of Science and Technology, 130 Meilong Rd., Shanghai 200237, China; xphe@ecust.edu.cn

4 Department of Chemistry, University of Bath, Bath BA2 7AY, UK

5 School of Chemistry and Chemical Engineering, Henan Normal University, Xinxiang 453007, China

* Correspondence: douweitao123@163.com (W.-T.D.); chstdj@bath.ac.uk (T.D.J.); bcye@ecust.edu.cn (B.-C.Y.)

+ These authors contributed equally to this work.

Abstract: Glycated haemoglobin $\left(\mathrm{HbA}_{1 \mathrm{c}}\right)$ is a diagnostic biomarker for type 2 diabetes. Traditional analytical methods for haemoglobin $(\mathrm{Hb})$ detection rely on chromatography, which requires significant instrumentation and is labour-intensive; consequently, miniaturized devices that can rapidly sense $\mathrm{HbA}_{1 \mathrm{c}}$ are urgently required. With this research, we report on an aptamer-based sensor (aptasensor) for the rapid and selective electrochemical detection of $\mathrm{HbA}_{1 \mathrm{c}}$. Aptamers that specifically bind $\mathrm{HbA}_{1 \mathrm{c}}$ and $\mathrm{Hb}$ were modified with a sulfhydryl and ferrocene group at the $3^{\prime}$ and $5^{\prime}$-end, respectively. The modified aptamers were coated through sulfhydryl-gold self-assembly onto screen printed electrodes, producing aptasensors with built in electroactivity. When haemoglobin was added to the electrodes, the current intensity of the ferrocene in the sensor system was reduced in a concentration-dependent manner as determined by differential pulse voltammetry. In addition, electrochemical impedance spectroscopy confirmed selective binding of the analytes to the aptamer-coated electrode. This research offers new insight into the development of portable electrochemical sensors for the detection of $\mathrm{HbA}_{1 \mathrm{c}}$.

Keywords: glycated haemoglobin; aptamer; electrochemical sensor

\section{Introduction}

The American Diabetes Association and World Health Organization have reported that blood concentrations of $\mathrm{HbA}_{1 \mathrm{c}}$ over $6.5 \%$ are linked with the development of diabetes mellitus [1-3]. Accurate detection of $\mathrm{HbA}_{1 \mathrm{c}}$ is of significant clinical value in screening, early diagnosis, treatment, and monitoring of complications associated with diabetes. Currently, a number of analytical methods for $\mathrm{HbA}_{1 \mathrm{c}}$ detection are available for clinical practice, including ion exchange chromatography, gel electrophoresis, turbidity immunoassay and enzymatic methods [4-7]. However, owing to issues such as the requirement of operational complexity of the instrumentation and cost, miniaturized sensors that can rapidly detect $\mathrm{HbA}_{1 \mathrm{c}}$ are urgently needed. Compared with the existing technology, aptamer-based electrochemical biosensors exhibit many advantages including (1) extended stability, (2) minimal blood for testing is required, and (3) using an aptamer [8-11] means that cast-type screen printing electrode construction of electrochemical sensors [12-15] can be used, which is convenient, enables miniaturization, and is low cost. Testing of $\mathrm{HbA}_{1 \mathrm{c}}$ is commonly 
recommended by several countries for monitoring the development of diabetes. The Chinese Medical Association's China Guideline for Type 2 Diabetes (2020 edition) [16] designated that laboratory measurements with strict quality control and the standardized test method for determination of glycosylated haemoglobin $\left(\mathrm{HbA}_{1 \mathrm{c}}\right)$ can be used as a diagnostic criterion for diabetes, where the threshold for the diagnosis of diabetes is $6.5 \% \mathrm{HbA}_{1 \mathrm{c}}$ or higher. According to the results of the laboratory quality assessment conducted by the Clinical Laboratory Center of the National Health Commission and the Shanghai Clinical Laboratory Center, standardization of the $\mathrm{HbA}_{1 \mathrm{c}}$ test in China has gradually improved, but there are still large differences amongst different regions and methods [17]. Encouragingly, since the quality of current $\mathrm{HbA}_{1 \mathrm{c}}$ monitoring systems are sub-optimal, excellent development opportunities and prospects exist. At present, the $\mathrm{HbA}_{1 \mathrm{c}}$ measurement instruments used in clinical laboratories in China are mostly imported and are very expensive. Therefore, development of an accurate, rapid, economical, and practical detection method is the goal of this research.

Consequently, with this research, we developed a simple, efficient, and low-cost electrochemical biosensor (Scheme 1) [18-22], which uses a low-cost screen-printed electrode as the test electrode. Two aptamer sequences were synthesized according to a previous study [23] with ferrocene and sulfhydryl denoted as Fc and SH, respectively:
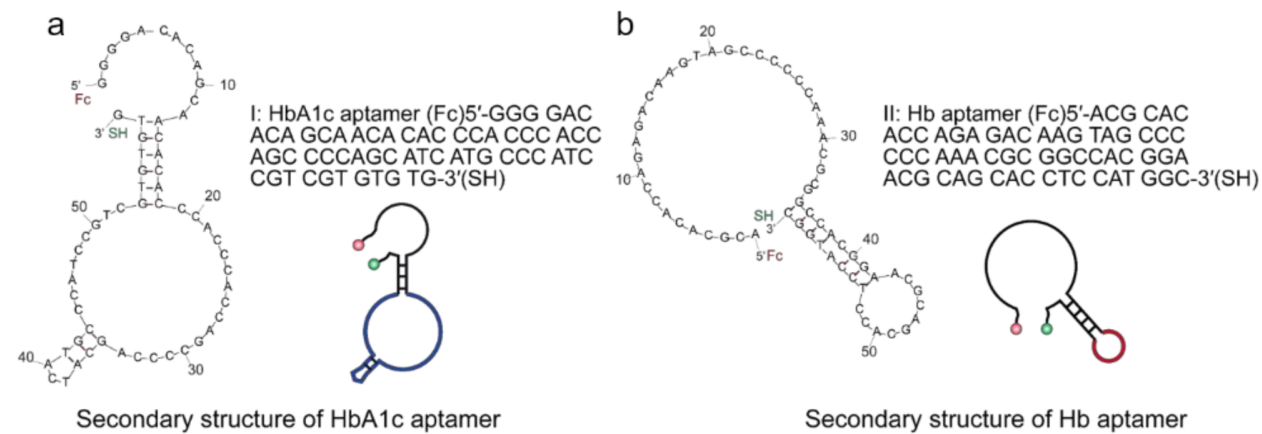

Secondary structure of $\mathrm{HbA} 1 \mathrm{c}$ aptamer

Secondary structure of $\mathrm{Hb}$ aptamer

C
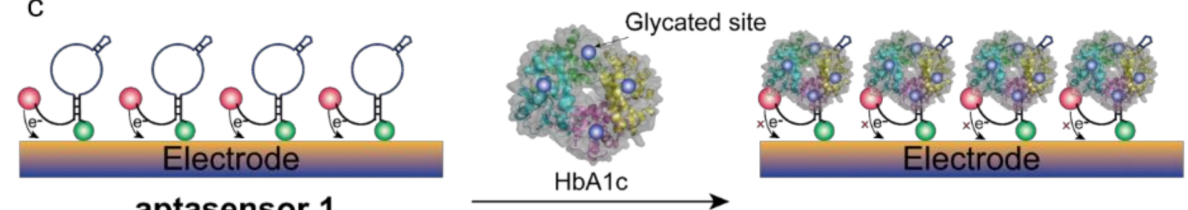

aptasensor 1

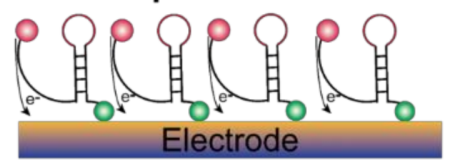

aptasensor 2

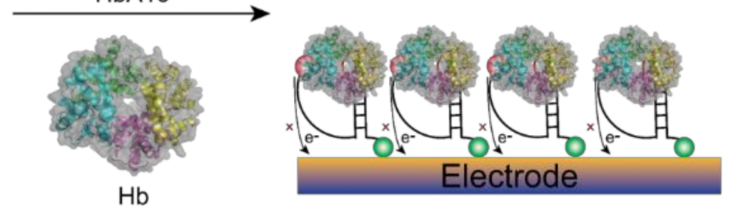

Scheme 1. Representative predicted secondary structures of (a) $\mathrm{Hb}$ aptamer ((Fc) $5^{\prime}-\mathrm{GGG}$ GAC ACA GCA ACA CAC CCA CCC ACC AGC CCC AGC ATC ATG CCC ATC CGT CGT GTG TG-3'(SH)), and (b) HbAlc aptamer ((Fc)5'-ACG CAC ACC AGA GAC AAG TAG CCC CCC AAA CGC GGC CAC GGA ACG CAG CAC CTC CAT GGC-3'(SH)) simulated using Mfold software. (c) Schematic illustration of the construction of aptasensors 1 and 2 through sulfhydryl-gold self-assembly on screen printed electrodes, and the plausible sensing mechanism of the functionalized aptasensors for haemoglobin $(\mathrm{Hb})$ (with aptasensor (1) and glycated haemoglobin (HbA1c) (with aptasensor (2); the presence of the proteins increases the distance from the electroactive ferrocene to the electrode surface, thereby impeding the electron transfer process.

I: $\mathrm{HbA}_{1 \mathrm{c}}$ aptamer $(\mathrm{Fc}) 5^{\prime}$-GGG GAC ACA GCA ACA CAC CCA CCC ACC AGC CCC AGC ATC ATG CCC ATC CGT CGT GTG TG-3'(SH)

II: $\mathrm{Hb}$ aptamer $(\mathrm{Fc}) 5^{\prime}$-ACG CAC ACC AGA GAC AAG TAG CCC CCC AAA CGC GGC CAC GGA ACG CAG CAC CTC CAT GGC-3'(SH). 
The aptamer system is constructed using a ferrocene as an electrical signal unit linked through the thiol self-assembled coating to a screen-printed gold electrode. After the $\mathrm{HbA}_{1 \mathrm{c}}$ aptamer interacts with a specific protein, the electrical signal of the ferrocene in solution changes. The ratio between $\mathrm{HbA}_{1 \mathrm{c}}$ and non- $\mathrm{HbA}_{1 \mathrm{c}}$ can then be used to predict the occurrence of diabetes mellitus. Upon binding of the aptamer with $\mathrm{HbA}_{1 \mathrm{c}}$, the long distance between ferrocene and electrode hinders the electron transfer, thereby diminishing current intensity [24].

\section{Results and Discussion}

In order to evaluate the use of cyclic voltammetry (CV) with the $\mathrm{HbA}_{1 \mathrm{c}}$ and $\mathrm{Hb}$ aptamer sensors, the sweep speed was set as $0.02-0.2 \mathrm{~V} / \mathrm{s}$ and the scanning range used was $0.2-0.6 \mathrm{~V}$. The cyclic voltammograms of the $\mathrm{HbA}_{1 \mathrm{c}}$ aptamer sensor (aptasensor 1) (Figure 1a) and $\mathrm{Hb}$ aptamer sensor (aptasensor 2) (Figure 1b) indicated that the aptamer sensors exhibited a Faradaic peak of $0.22 \mathrm{~V}$ and an oxidation peak of $0.13 \mathrm{~V}$; the two peaks are symmetric with a peak separation of $0.09 \mathrm{~V}$. According to the plot of the scanning speed against the test current, the current of the aptamer sensor in the electrolyte was proportional to the scanning speed. This demonstrated that the chemical behaviour was controlled by interfacial electron transfer. The correlation equations of the oxidation and reduction peak for the $\mathrm{HbA}_{1 \mathrm{c}}$ aptasensor (Figure 1c) were $y=10^{-4}+10^{-6}$ $\left(\mathrm{HbA}_{1 \mathrm{c}}\right.$ oxidation peak) $\left(R^{2}=0.948\right)$ and $Y=-10^{-4}-10^{-6} x\left(\mathrm{HbA}_{1 \mathrm{c}}\right.$ reduction peak) $\left(R^{2}=0.918\right)$, respectively. The correlation equations of the oxidation and reduction peak for the $\mathrm{Hb}$ aptasensor (Figure $1 \mathrm{~d}$ ) were $Y=4 \times 10^{-5}+3 \times 10^{-7} x(\mathrm{Hb}$ oxidation peak) $\left(R^{2}=0.950\right)$ and $Y=-3 \times 10^{-5}-3 \times 10^{-7} x(\mathrm{Hb}$ reduction peak $)\left(R^{2}=0.938\right)$, respectively. The amount $\left(\Gamma^{*}\right)$ of aptamer 1 and 2 immobilized on the electrode was calculated to be $3.98 \times 10^{-11} \mathrm{~mol} \mathrm{~cm}^{-2}$ and $1.89 \times 10^{-11} \mathrm{~mol} \mathrm{~cm}^{-2}$, respectively, according to the following equation $\Gamma^{*}=Q \times(n F A)^{-1}$ [25], where $Q$ is the charge involved in the reaction, $n$ is the number of transferred electrons, $\mathrm{F}$ is the Faraday constant and $\mathrm{A}$ is the geometric area of the electrode.
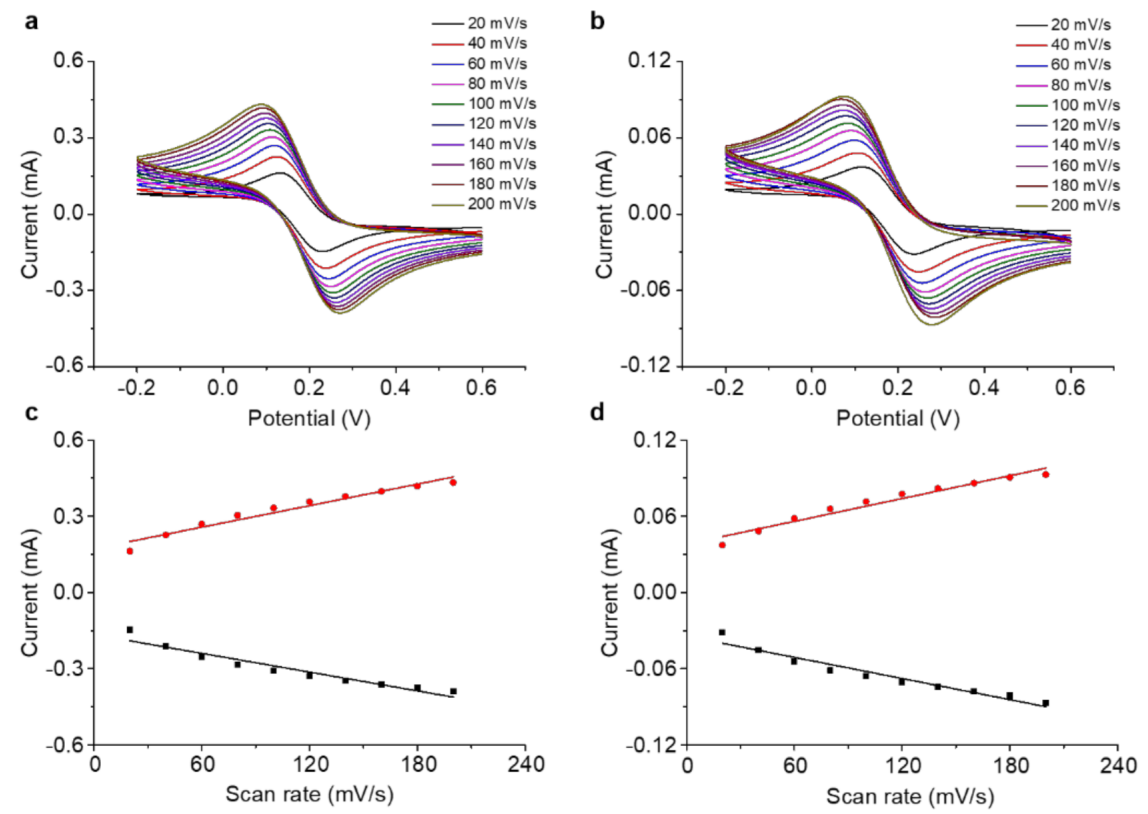

Figure 1. Cyclic voltametric curves of (a) aptasensor $\mathbf{1}$ and (b) aptasensor $\mathbf{2}$ with different scanning rates. Plotting the current intensity of (c) aptasensor $\mathbf{1}$ and (d) aptasensor $\mathbf{2}$ as a function of potential.

The impedance of the $\mathrm{HbA}_{1 \mathrm{c}}$ aptamer sensor in $\mathrm{HbA}_{1 \mathrm{c}}$ protein solutions with concentrations of $5.0,10.0,20.0,30.0$, and $40 \mu \mathrm{g} / \mathrm{mL}$ and the $\mathrm{Hb}$ aptamer sensor in $\mathrm{Hb}$ protein solutions with concentrations of $62.5 \mu \mathrm{g} / \mathrm{mL}, 125.0 \mu \mathrm{g} / \mathrm{mL}, 250.0 \mu \mathrm{g} / \mathrm{mL}, 500.0 \mu \mathrm{g} / \mathrm{mL}$, were 
evaluated in $5 \mathrm{mmol} / \mathrm{L}\left[\mathrm{Fe}(\mathrm{CN})_{6}\right]^{3-} /\left[\mathrm{Fe}(\mathrm{CN})_{6}\right]^{4-}$ and $0.1 \mathrm{~mol} / \mathrm{L} \mathrm{KCl}$ electrolyte [20-22]. The Nyquist plots of the $\mathrm{HbA}_{1 \mathrm{c}}$ and $\mathrm{Hb}$ impedance are shown in Figure 2a,b. With increasing protein concentration, the capacitive reactance arc in the high-frequency region gradually increased. More protein binds at higher polarization resistance, which indicates that both proteins had a certain blocking effect on the current transfer in the test solution, and the magnitude of the capacitive reactance arc reflects the magnitude of the binding protein action on the aptamer sensor.
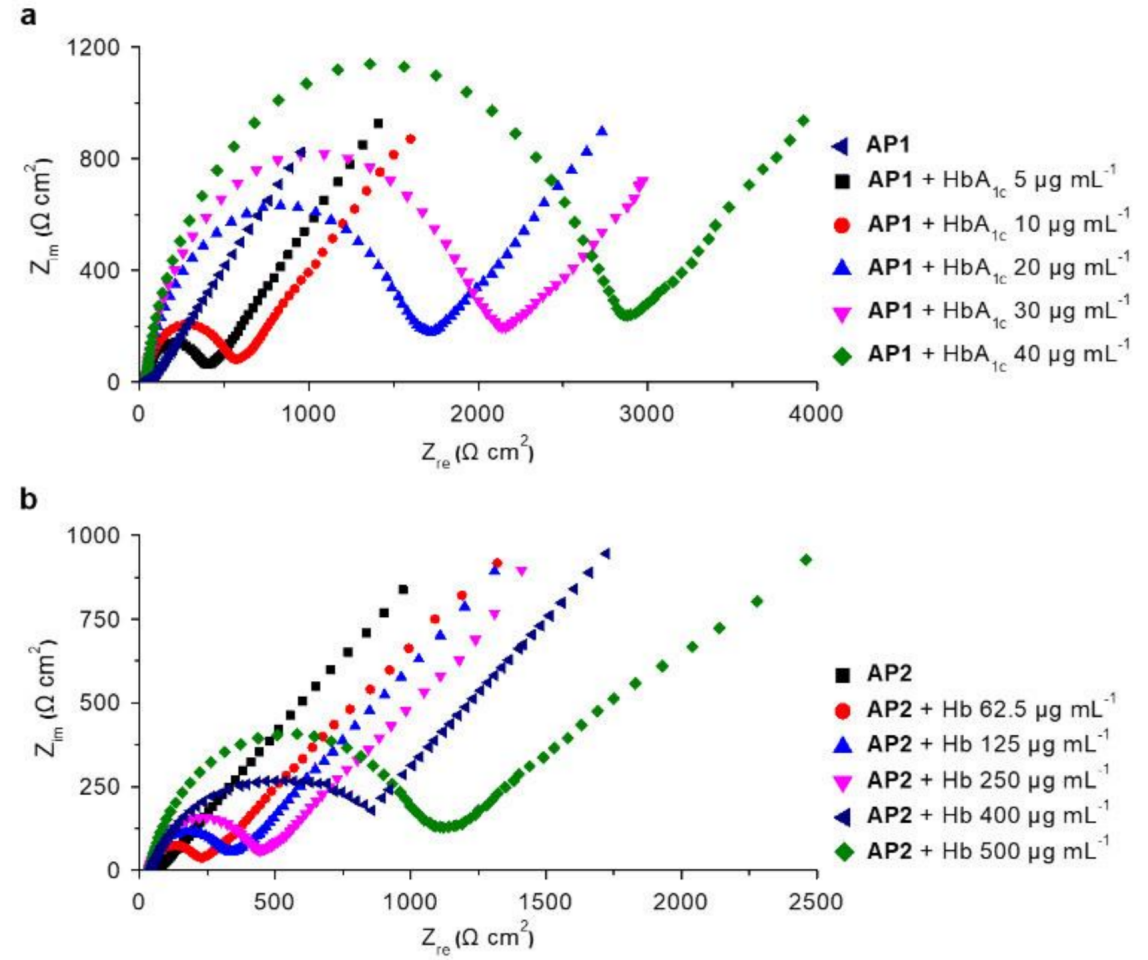

Figure 2. Impedimetric changes of (a) aptasensor $\mathbf{1}$ (AP1) with increasing $\mathrm{HbA}_{1 \mathrm{c}}$ and (b) aptasensor 2 (AP2) with increasing $\mathrm{Hb}$ measured by AC impedance spectroscopy.

The differential pulse voltammetry (DPV)-based detection of $\mathrm{HbA}_{1 \mathrm{c}}$ and $\mathrm{Hb}$ by the aptamer sensors was achieved according to the protocol shown in the experimental section. The changes of the peak currents after binding of the corresponding proteins to the $\mathrm{HbA}_{1 \mathrm{c}}$ and $\mathrm{Hb}$ aptamer sensors were determined by the DPV method (Figure 3a,b, respectively). The aptamer sensor response without protein addition was used as a control to quantitatively detect the corresponding protein. The protein concentration was used as the $X$ axis and the peak current was the $Y$ axis. The fitting curves of $\mathrm{HbA}_{1 \mathrm{c}}$ and $\mathrm{Hb}$ are shown in Figure $3 c, d$, respectively. The fitting equations and correlation coefficients were as follows: $Y=10^{-6} x /(11.740+x)\left(R^{2}=0.969\right)$ and $Y=10^{-6} x /(95.916+x)\left(R^{2}=0.968\right)$. The dissociation constant $\left(K_{\mathrm{d}}\right)$ of $\mathrm{HbA}_{1 \mathrm{c}}$ was $11.7 \pm 3.3 \mu \mathrm{g} / \mathrm{mL}$, and that of $\mathrm{Hb}$ was $95.9 \pm 40.0 \mu \mathrm{g} / \mathrm{mL}$ as calculated via the equation $\mathrm{Y}=B_{\max } \mathrm{X} /\left(K_{\mathrm{d}}+\mathrm{X}\right)$, where $\mathrm{Y}$ is the current intensity of the aptasensor in the presence of a protein, $X$ is the concentration of the protein, and $B_{\max }$ and $K_{\mathrm{d}}$ are the slope and intercept of the equation, respectively. Data were analyzed using Origin 8.5 (OriginLab Corporation). The linear range of the aptasensors were determined to be $0.1-14 \mu \mathrm{g} / \mathrm{mL}\left(R^{2}=0.97\right)$ and $1-140 \mu \mathrm{g} / \mathrm{mL}\left(R^{2}=0.95\right)$ for $\mathrm{HbA}_{1 \mathrm{c}}$ and $\mathrm{Hb}$, respectively. The limit of detection of the aptasensors were calculated to be $84 \mathrm{pg} / \mathrm{mL}$ and $237 \mathrm{pg} / \mathrm{mL}$ for $\mathrm{HbA}_{1 \mathrm{c}}$ and $\mathrm{Hb}$, respectively $(3 \sigma / \mathrm{k}$, where $\sigma$ is the standard deviation of the instrument and $\mathrm{k}$ is the slope of the plots shown in Figure $3 \mathrm{c}, \mathrm{d}$. 

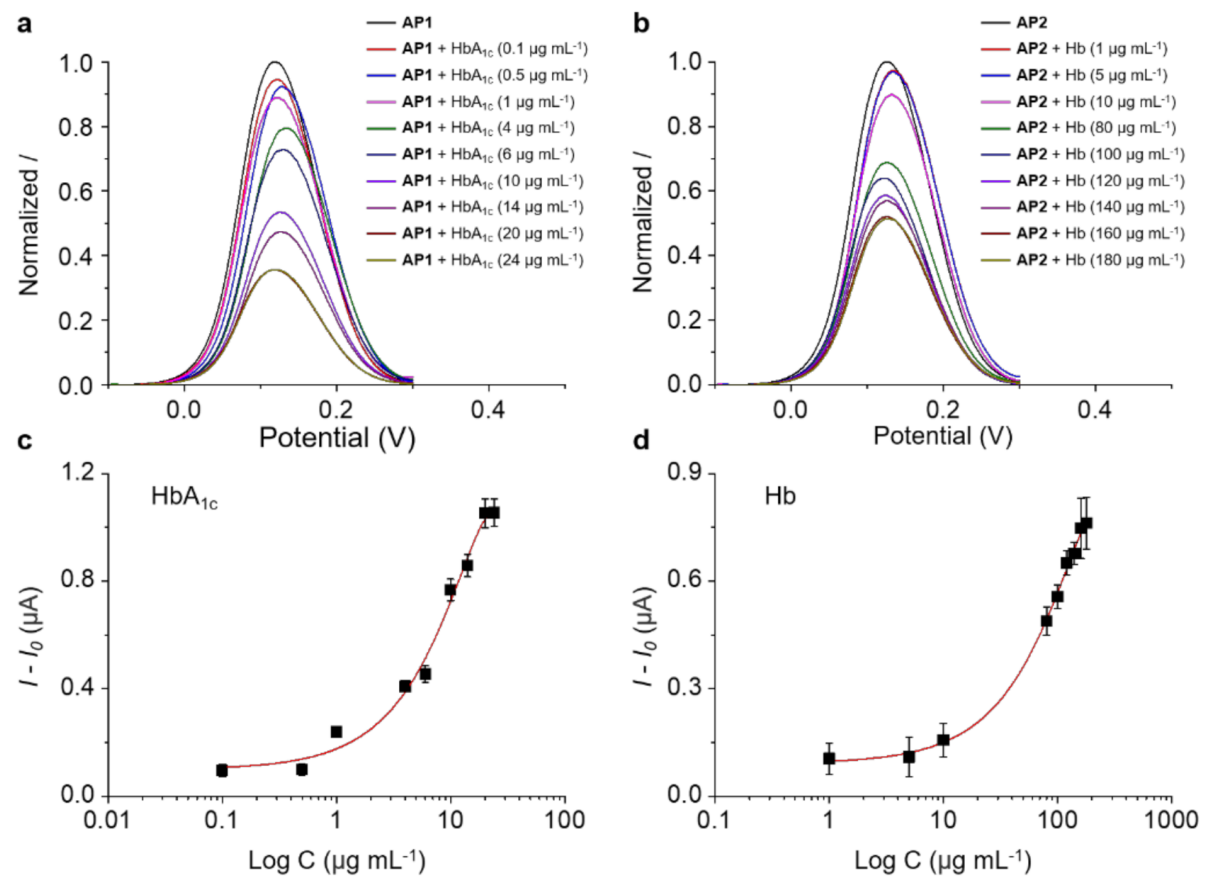

Figure 3. Differential pulse voltametric curves of (a) aptasensor $\mathbf{1}$ (AP1) with increasing $\mathrm{HbA}_{1 \mathrm{c}}$ and (b) aptasensor 2 (AP2). The current intensity $(I)$ of an aptasensor in the absence of $\mathrm{HbA} 1 \mathrm{c}$ or $\mathrm{Hb}$ is normalized to that of the aptasensor in the presence of $\mathrm{HbA1c}$ or $\mathrm{Hb}$. (c) Plotting the current changes of aptasensor $\mathbf{1}$ (AP1) with increasing $\mathrm{HbA}_{1 \mathrm{c}}$, and (d) Plotting the current changes of aptasensor 2 (AP2) with increasing $\mathrm{Hb}$, where $I$ and $I_{0}$ are the current intensity of an aptasensor in the presence and absence of protein analyte, respectively. Error bars mean standard deviation $(n=3)$.

According to the $\mathrm{HbA}_{1 \mathrm{c}}$ and $\mathrm{Hb}$ protein concentrations in Table 1, the DPV method was performed according to the established detection method. The protein concentration was used as the $X$ axis and the peak current was the $Y$ axis (Figure 4a,b); data for a broader protein concentration range are given in Table S1 and Figure S5. The second-order fitting equations for $\mathrm{HbA}_{1 \mathrm{c}}$ and $\mathrm{Hb}$ were $\mathrm{y}=-7 \times 10^{-10} \mathrm{x}^{2}+5 \times 10^{-8} \mathrm{x}+3 \times 10^{-7}\left(R^{2}=0.960\right)$ and $y=-5 \times 10^{-11} x^{2}+2 \times 10^{-8} X-7 \times 10^{-7}\left(R^{2}=0.952\right)$ [26], respectively. The results indicated that the $\mathrm{HbA}_{1 \mathrm{c}}$ concentration was in the range $2.0-22.0 \mu \mathrm{g} / \mathrm{mL}$ and the $\mathrm{Hb}$ concentration was in the range $80.0-160 \mu \mathrm{g} / \mathrm{mL}$. The clinical detection range of $\mathrm{HbA}_{1 \mathrm{c}}$ protein $/ \mathrm{Hb}$ protein was calculated to be in the range of $4.4 \%-14.7 \%(25.0-137.5 \mathrm{mmol} / \mathrm{mol})$. The results suggest that the signal change of both aptasensors correlates well to the protein concentration ranges typically detected in the blood, which could be potentially applicable for clinical application.

Table 1. Concentration of $\mathrm{HbA}_{1 \mathrm{c}}$ and $\mathrm{Hb}$, and clinically relevant detection range of $\mathrm{HbA}_{1 \mathrm{c}}$ and $\mathrm{Hb}$.

\begin{tabular}{ccccccc}
\hline Species & Units & Con.1 & Con.2 & Con.3 & Con.4 & Con.5 \\
\hline $\mathrm{HbA}_{1 \mathrm{c}}$ & $\mu \mathrm{g} / \mathrm{mL}$ & 2 & 6 & 12 & 16 & 22 \\
$\mathrm{Hb}$ & $\mu \mathrm{g} / \mathrm{mL}$ & 80 & 100 & 120 & 140 & 160 \\
$\mathrm{HbA}_{1 \mathrm{c}} / \mathrm{Hb}$ & $\mathrm{mmol} / \mathrm{mol}$ & 25 & 60 & 100 & 114 & 137.5 \\
$\mathrm{NGSP}$ & $\%$ & 4.4 & 7.6 & 11.3 & 12.6 & 14.7 \\
\hline
\end{tabular}



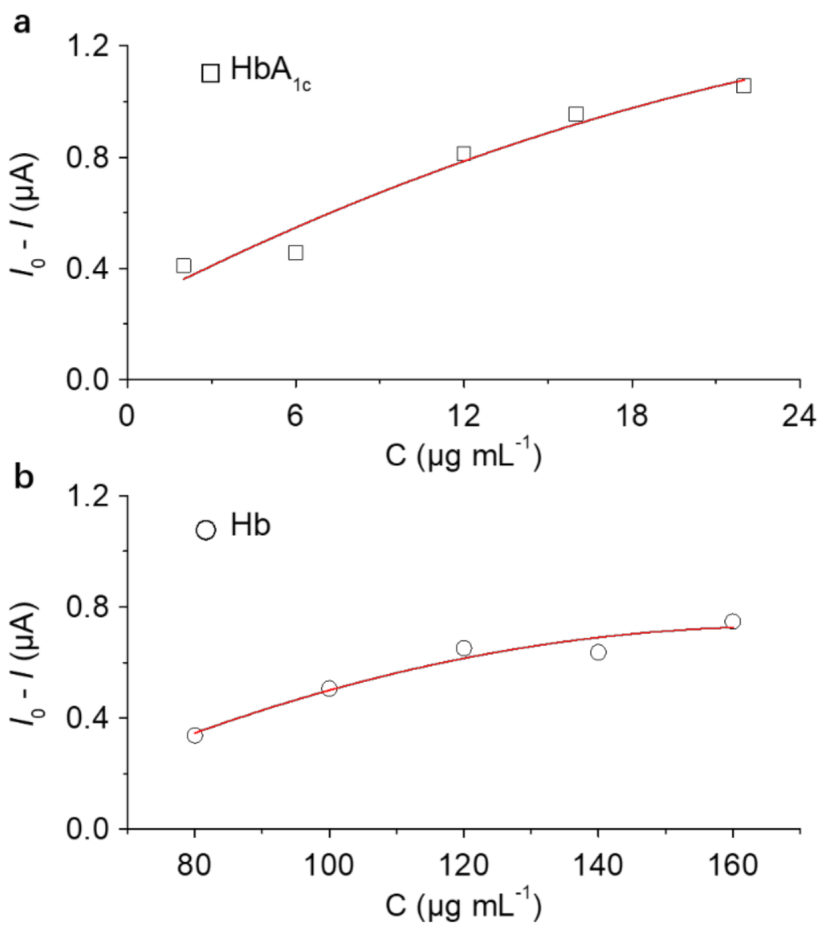

Figure 4. (a) Plotting the current changes of aptasensor 1 with increasing $\mathrm{HbA}_{1 c}$, and (b) plotting the current changes of aptasensor 2 with increasing $\mathrm{Hb}$, where $I$ and $I_{0}$ are the current intensity of an aptasensor in the presence and absence of protein analyte, respectively.

Abnormal $\mathrm{HbA}_{1 \mathrm{c}}$ levels are a common pathophysiological basis for type 2 diabetes mellitus (T2DM) and pancreatic cancer, and it is observed long before the clinical symptoms of these diseases appear. Existing methods for the detection and evaluation of diabetes include microcolumn ion-exchange chromatography, affinity chromatography, high-performance liquid chromatography (HPLC), immunofluorescence, ion capture, and electrophoresis. The high-pressure liquid-phase method is considered to be the gold standard for $\mathrm{HbA}_{1 \mathrm{c}}$ detection. At present, clinical laboratories typically use liquid chromatography detection methods for $\mathrm{HbA}_{1 \mathrm{c}}$ detection. However, the dependence on large machines reduces patient compliance, and affects the effective management of diabetes. To date the use of point-of-care (POC) instruments for detection of $\mathrm{HbA}_{1 \mathrm{c}}$ in clinical laboratories has not been investigated. Currently, $\mathrm{HbA}_{1 \mathrm{c}}$ analysers have only been used in clinical trials for POC, so the creation of sensitive micro- $\mathrm{HbA}_{1 \mathrm{c}}$ biosensors is still a work in progress.

Accurate POC devices for $\mathrm{HbA}_{1 \mathrm{c}}$ evaluation are essential, but their development is constrained by the cost of the testing systems. Because T2DM is a progressive disease, early screening of the blood glucose status is an effective method for the treatment and management of early-stage diabetes, and it is very important to reduce the number of missed diabetes diagnoses. The electrochemical biosensor method established in this study for the detection of $\mathrm{HbA}_{1 \mathrm{c}}[27,28]$ is simple to operate and inexpensive, and as such is suitable for general clinical use. The linear relationship of this method is over a range from $4.4 \%$ to $14.7 \%$ NGSP units and meets the requirements of clinical analysis. DPV tests indicated that the peak currents of both aptamer sensors gradually decreased with increasing protein concentrations. This was because the aptamer bound to the protein and formed a protein coating on the surface of the sensor to block electron transfer of the Fc group. From the Nyquist plots obtained from the impedance experiments, regardless of the presence or absence of the protein (blank), the shapes of the impedance spectra were similar, which was a flattened semicircular capacitive reactance arc with an inclined upward line (Warburg impedance). This "repressed" semicircular capacitive reactance arc is caused by frequency diffusion, which in turn is related to the interface uniformity, defects, and protein adsorption on the electrode surface. The Warburg diffusion line at the 
end of the spectrum is caused by diffusion. In addition, the size of the capacitive reactance arc reflects the size of the polarization resistance of the system. The polarization resistance is higher for a larger capacitive reactance arc, which means that the corresponding binding current density is smaller (that is, more protein binding).

\section{Materials and Methods}

\subsection{General}

All of the chemicals and reagents used were of analytical grade. Sodium dihydrogen phosphate monohydrate $\left(\mathrm{NaH}_{2} \mathrm{P}_{3} \mathrm{O}_{4} \cdot \mathrm{H}_{2} \mathrm{O}\right)$, disodium hydrogen phosphate $\left(\mathrm{Na}_{2} \mathrm{HP}_{3} \mathrm{O}_{4} \cdot \mathrm{H}_{2} \mathrm{O}\right)$, magnesium chloride $\left(\mathrm{MgCl}_{2}\right)$, tris (hydroxymethyl) aminoethane (Tris), sodium chloride $(\mathrm{NaCl})$, hydrochloric acid $(\mathrm{HCl})$, sodium hydroxide $(\mathrm{NaOH})$, sulfuric acid $\left(\mathrm{H}_{2} \mathrm{SO}_{4}\right)$, potassium chloride $(\mathrm{KCl})$, ethanol $\left(\mathrm{CH}_{3} \mathrm{CH}_{2} \mathrm{OH}\right)$, mercaptoethanol $(\mathrm{MEH})$, and potassium ferricyanide $\left(\mathrm{K}_{3}\left[\mathrm{Fe}(\mathrm{CN})_{6}\right] \cdot 3 \mathrm{H}_{2} \mathrm{O}\right.$ and $\left.\mathrm{K}_{4}\left[\mathrm{Fe}(\mathrm{CN})_{6}\right] \cdot 3 \mathrm{H}_{2} \mathrm{O}\right)$ were purchased from Sigma-Aldrich. The disulfide bond reducing agent tris(2-formyl ethyl) phosphine hydrochloride (TCEP) was obtained from Thermo Fisher, Inc. $\mathrm{HbA}_{1 \mathrm{c}}$ aptamer (Figures $\mathrm{S} 1$ and $\mathrm{S} 2$ ) and $\mathrm{Hb}$ aptamer (Figures S3 and S4) with a purity of 98\% were synthesized by Sangon Bioengineering (Shanghai) Co., Ltd. $\mathrm{HbA}_{1 \mathrm{c}}$ protein and $\mathrm{Hb}$ protein were purchased from Prospec Corporation. All experiments used ultrapure water (resistivity $18.2 \mathrm{M} \Omega / \mathrm{cm}$ ).

\subsection{Apparatus}

A CHI660E electrochemical workstation (Shanghai CH Instruments Ins., China) and screen-printed electrodes (220AT, Dropsense, Swiss) were used. The screen-printed electrodes consist of a three-electrode system: gold ( $\mathrm{Au}$, inner diameter $=4 \mathrm{~mm}$ ) or aptamermodified gold as the working electrode, gold as the counter electrode, and a silver electrode used as the reference electrode.

\subsection{Preparation of Aptamer Biosensor}

Electrodes were immersed in a $0.05 \mathrm{~mol} / \mathrm{L} \mathrm{NaOH}$ solution and scanned by $\mathrm{CV}$ until the signal is stable with a scanning range of $-0.3 \mathrm{~V}-1.3 \mathrm{~V}$ and scanning speed of $0.1 \mathrm{~V} / \mathrm{s}$. Electrodes were then treated under ultrasound in $100 \%$ ethanol and ultrapure water for $3 \mathrm{~min}$. Subsequently, the electrodes were rinsed under ultrasound sequentially in $0.5 \mathrm{mmol} / \mathrm{L} \mathrm{H}_{2} \mathrm{SO}_{4}, 0.1 \mathrm{mmol} / \mathrm{L} \mathrm{KCl}$, and ultrapure water, followed by drying with $\mathrm{N}_{2}$ prior to use. $\mathrm{HbA} 1 \mathrm{c}$ or $\mathrm{Hb}$ aptamer was diluted to a final concentration of $5 \mu \mathrm{mol} / \mathrm{L}$ with $\mathrm{TM}$ solution $(5 \mathrm{mmol} / \mathrm{L} \mathrm{MgCl}$ and $10 \mathrm{mmol} / \mathrm{L}$ Tris- $\mathrm{HCl})$, to which was added a tris(2-formyl ethyl)phosphine hydrochloride solution (TCEP, concentration: $3 \mathrm{mmol} / \mathrm{L}$ ) to reduce disulfide bonds. Then, the mixture was annealed at $37{ }^{\circ} \mathrm{C}$ for $20 \mathrm{~min}$. Next, $3 \mu \mathrm{L}$ of an aptamer solution was dropped onto the prepared electrodes, which were then incubated at room temperature for $16 \mathrm{~h}$, rinsed three times with phosphate-buffered saline (PBS, $0.1 \mathrm{~mol} / \mathrm{L}, \mathrm{pH} 6.5,1 \mathrm{mM} \mathrm{MgCl} 2$ ), and then dried with $\mathrm{N}_{2}$ prior to use.

\subsection{Cyclic Voltammetry (CV)}

$\mathrm{CV}$ was performed with a computer-controlled $\mathrm{CHI760E}$ electrochemical workstation (Chenhua Co., Ltd., Shanghai, China) between 0.2 and $0.6 \mathrm{~V}$ (vs. $\mathrm{Ag} / \mathrm{AgCl}$ ) at scan rates ranging from 0 to $200 \mathrm{mV} / \mathrm{s}$. The electrolyte $\left(5 \mathrm{mmol} / \mathrm{L} \mathrm{K}_{3}\left[\mathrm{Fe}(\mathrm{CN})_{6}\right], 5 \mathrm{mmol} / \mathrm{L}\right.$ $\left.\mathrm{K}_{4}\left[\mathrm{Fe}(\mathrm{CN})_{6}\right] \cdot 3 \mathrm{H}_{2} \mathrm{O} / 0.1 \mathrm{~mol} / \mathrm{L} \mathrm{KCl}\right)$ was degassed with $\mathrm{N}_{2}$ for 20 min before measurements. The screen-printed electrodes (SPEs) were pre-treated in $\mathrm{NaOH}(0.05 \mathrm{~mol} / \mathrm{L}), \mathrm{H}_{2} \mathrm{SO}_{4}$ $(0.5 \mathrm{mmol} / \mathrm{L}), \mathrm{H}_{2} \mathrm{SO}_{4}(0.5 \mathrm{mmol} / \mathrm{L}$ containing $0.1 \mathrm{mmol} / \mathrm{L} \mathrm{KCl})$ solution, and $\mathrm{H}_{2} \mathrm{SO}_{4}$ $(0.05 \mathrm{mmol} / \mathrm{L})$ by applying an anodic potential (scanning range -0.2 to $0.6 \mathrm{~V}$, scanning speed $0.1 \mathrm{~V} / \mathrm{s}$ (vs. $\mathrm{Ag} / \mathrm{AgCl}$ ) for $2 \mathrm{~s}$ ), and they were then washed with ultrapure water and blown dry with $\mathrm{N}_{2}$ for use. The circular area (4 $\mathrm{mm}$ in diameter) was used as the working electrode, the reference electrode was printed with gold paste, and the auxiliary electrode was printed with $\mathrm{AgCl}$ as silver paste. For functionalization of the SPEs, a drop of the aptamer solution $(5 \mu \mathrm{L})$ was dropped onto the working electrode and then dried 
under vacuum. The functionalized SPEs were then immersed in the electrolyte to record the cyclic voltammograms.

\subsection{Differential Pulse Voltammetry (DPV)}

DPV was performed with an amplitude of $0.5 \mathrm{~V}$, a pulse width of $0.05 \mathrm{~s}$, a standing time of $2 \mathrm{~s}$, and a scanning range from -0.1 to $0.3 \mathrm{~V}$ in $\mathrm{TM}\left(5 \mathrm{mmol} / \mathrm{L} \mathrm{MgCl}_{2}, 10 \mathrm{mmol} / \mathrm{L}\right.$ Tris- $\mathrm{HCl}, \mathrm{pH}$ 6.5). For detection of the analytes, drops $(5 \mu \mathrm{L})$ of the analyte solution (dissolved in phosphate-buffered saline or Tris- $\mathrm{HCl}$ ) with different concentrations were dropped onto the aptamer-functionalized working electrode area of the SPE and incubated for $90 \mathrm{~min}$. The electrodes were then rinsed with buffer solution three times, dried at room temperature, and immersed in degassed buffer for measurement.

Electrochemical impedance spectroscopy (EIS) [29-32]. EIS was performed with a CHI760E electrochemical workstation in the presence of an $\left[\mathrm{Fe}(\mathrm{CN})_{6}\right]^{3-} /\left[\mathrm{Fe}(\mathrm{CN})_{6}\right]^{4-}$ $(5 \mathrm{mmol} / \mathrm{L})$ redox couple in $0.1 \mathrm{M} \mathrm{KCl}$ solution over a frequency range from $10 \mathrm{mHz}$ to $100,000 \mathrm{~Hz}$ (perturbation signal $5 \mathrm{mV}$ ). All of the collected data were fitted using ZSimpWin software. The aptamer solution $(5 \mu \mathrm{L})$ was first dropped onto the working electrode area of the SPE, dried under vacuum, and then the Nyquist plots were recorded. For detection of the sugar-lectin interactions, a drop of protein solution (Tris-HCl, $5 \mu \mathrm{L}$ ) was dropped onto the aptamer-functionalized electrode [33-36], dried under vacuum, and then the Nyquist plots were recorded.

\subsection{Application of The Aptamer Sensors for Clinical Detection}

In accordance with the requirements for clinical testing, different concentrations of protein samples with protein molecular weight of 63,000 were tested using the unit conversion formula IFCC $(\mathrm{mmol} / \mathrm{mol})=10.93 \times$ NGSP $($ National Glycohemoglobin Standardization Program) (\%) -23.5 by DPV in $10 \mathrm{mmol} / \mathrm{L}$ Tris- $\mathrm{HCl}$ solution. Each sample was tested three times. The mean of the peak current test results were calculated using the protein concentration as the $X$ axis and the peak current as the $Y$ axis. Analysis by second-order linear fitting gave the relevant equations, correlation coefficient $(r)$, and detection range.

\subsection{Statistical Analysis}

Microsoft Excel software was used to analyze the test data for evaluation of clinical detection application of the adapter sensors. Origin 8.5 software was used to analyze the alternating current $(\mathrm{AC})$ impedance test data of the protein on the adapter sensor, method for detecting $\mathrm{HbA}_{1 \mathrm{c}}$ and $\mathrm{Hb}$ by the adapter sensor, and the test data of the influence of the scanning speed on the signal of the adapter sensor.

\section{Conclusions}

The reported method has the advantages of small sample size, convenient operation, miniaturization, and low cost. We are currently working to expand our system to monitor both healthy and diseased populations in China in order to provide reference data for detection of $\mathrm{HbA}_{1 \mathrm{c}}$ using our POC system.

Supplementary Materials: The following are available online, Figure S1: Mass spectrum of $\mathrm{HbA}_{1 \mathrm{c}}$ aptamer (I), Figure S2: HPLC of $\mathrm{HbA}_{1 \mathrm{c}}$ aptamer (I), Figure S3: Mass spectrum of $\mathrm{Hb}$ aptamer (II), Figure S4: HPLC of $\mathrm{Hb}$ aptamer (II), Table S1: Concentration used for $\mathrm{HbA1c}$ and $\mathrm{Hb}$, Figure S5: Plotting the current changes of the aptasenors as a function of protein concentration.

Author Contributions: Conceptualization, Y.J. and X.-P.H.; methodology, X.-Q.F. and W.-T.D.; validation, X.-Q.F., Y.J., Q.L. and W.-T.D.; formal analysis, X.-Q.F., Q.L. and Z.-G.J.; investigation, X.-Q.F. and W.-T.D.; resources, Y.J. and X.-P.H.; data curation, Y.J.; writing—original draft preparation, X.-Q.F., Y.J. and W.-T.D.; writing-review and editing, X.-Q.F., X.-P.H., T.D.J. and B.-C.Y.; supervision, B.-C.Y.; project administration, B.-C.Y.; funding acquisition, Y.J. and B.-C.Y. All authors have read and agreed to the published version of the manuscript. 
Funding: This research was funded by the National Natural Science Foundation of China (22107028), Natural Science Foundation of Shanghai (19ZR1445600), the Shanghai Science and Technology Committee (19410712600), National Postdoctoral Program for Innovative Talents (BX20190115), Shanghai Post-doctoral Excellence Program (2019044) and China Postdoctoral Science Foundation (2020M681206) for financial support. T.D.J. wishes to thank the Royal Society for a Wolfson Research Merit Award and the Open Research Fund of the School of Chemistry and Chemical Engineering, Henan Normal University for support (2020ZD01).

Institutional Review Board Statement: Not applicable.

Informed Consent Statement: Not applicable.

Data Availability Statement: Not applicable.

Conflicts of Interest: The authors declare no competing interests.

Sample Availability: Not applicable.

\section{References}

1. Schütze, D. One-dimensional diffusions with discontinuous scale. Z. Wahrscheinlichkeitstheorie Verwandte Geb. 1979, 49, 97-104. [CrossRef]

2. Practice, C. Use of glycated haemoglobin (HbA1c) in the diagnosis of diabetes mellitus. Diabetes Res. Clin. Pract. 2011, 93, 299-309. [CrossRef]

3. Li, F.R.; Zhang, X.R.; Zhong, W.F.; Li, Z.H.; Gao, X.; Kraus, V.B.; Lv, Y.B.; Zou, M.C.; Chen, G.C.; Chen, P.L.; et al. Glycated hemoglobin and all-cause and cause-specific mortality among adults with and without diabetes. J. Clin. Endocrinol. Metab. 2019, 104, 3345-3354. [CrossRef] [PubMed]

4. Little, R.R. Performance of hemoglobin A1c assay methods: Good enough? Clin. Chem. 2014, 60, 1031-1033. [CrossRef]

5. John, W.G. Haemoglobin A1c: Analysis and standardisation. Clin. Chem. Lab. Med. 2003, 41, 1199-1212. [CrossRef]

6. Mostafa, S.A.; Davies, M.J.; Srinivasan, B.T.; Carey, M.E.; Webb, D.; Khunti, K. Should glycated haemoglobin (HbA1c) be used to detect people with type 2 diabetes mellitus and impaired glucose regulation? Postgrad. Med. J. 2010, 86, 656-662. [CrossRef]

7. Sharma, P.; Panchal, A.; Yadav, N.; Narang, J. Analytical techniques for the detection of glycated haemoglobin underlining the sensors. Int. J. Biol. Macromol. 2020, 155, 685-696. [CrossRef]

8. Meng, H.M.; Liu, H.; Kuai, H.; Peng, R.; Mo, L.; Zhang, X.B. Aptamer-integrated DNA nanostructures for biosensing, bioimaging and cancer therapy. Chem. Soc. Rev. 2016, 45, 2583-2602. [CrossRef]

9. Zhang, Z.; Oni, O.; Liu, J. New insights into a classic aptamer: Binding sites, cooperativity and more sensitive adenosine detection. Nucleic Acids Res. 2017, 45, 7593-7601. [CrossRef]

10. Mayer, M.; Baeumner, A.J. A megatrend challenging analytical chemistry: Biosensor and chemosensor concepts ready for the internet of things. Chem. Rev. 2019, 119, 7996-8027. [CrossRef]

11. Munzar, J.D.; Ng, A.; Juncker, D. Duplexed aptamers: History, design, theory, and application to biosensing. Chem. Soc. Rev. 2019, 48, 1390-1419. [CrossRef]

12. Ranjan, R.; Esimbekova, E.N.; Kratasyuk, V.A. Rapid biosensing tools for cancer biomarkers. Biosens. Bioelectron. 2017, 87, 918-930. [CrossRef]

13. Ligler, F.S.; Gooding, J.J. Lighting up biosensors: Now and the decade to come. Anal. Chem. 2019, 91, 8732-8738. [CrossRef]

14. Putnin, T.; Waiwinya, W.; Pimalai, D.; Chawjiraphan, W.; Sathirapongsasuti, N.; Japrung, D. Dual sensitive and rapid detection of glycated human serum albumin using a versatile lead/graphene nanocomposite probe as a fluorescence-electrochemical aptasensor. Analyst 2021, 146, 4357-4364. [CrossRef]

15. Li, C.; Li, J.; Tang, H.; Yang, X.; Fei, Q.; Sun, C. A non-enzymatic electrochemical biosensor based on $\mathrm{SiO}_{2}$-Au nanoparticles for hemoglobin detection. Anal. Methods 2017, 9, 1265-1272. [CrossRef]

16. Jia, W.; Weng, J.; Zhu, D.; Ji, L.; Lu, J.; Zhou, Z.; Zou, D.; Guo, L.; Ji, Q.; Chen, L.; et al. Standards of medical care for type 2 diabetes in China 2019. Diabetes. Metab. Res. Rev. 2019, 35, 2. [CrossRef]

17. Ju, Y.; Li, Q.; Tang, L. Establishment of review criteria for Siemens Advia 2120 hematology analyzer and its application. Chin. J. Lab. Med 2018, 41, 804-807. [CrossRef]

18. Chen, H.H.; Wu, C.H.; Tsai, M.L.; Huang, Y.J.; Chen, S.H. Detection of total and A1c-glycosylated hemoglobin in human whole blood using sandwich immunoassays on polydimethylsiloxane-based antibody microarrays. Anal. Chem. 2012, 84, 8635-8641. [CrossRef]

19. Liu, H.; Crooks, R.M. Determination of percent hemoglobin A1c using a potentiometric method. Anal. Chem. 2013, 85, 1834-1839. [CrossRef]

20. Sun, J.; Xianyu, Y.; Jiang, X. Point-of-care biochemical assays using gold nanoparticle-implemented microfluidics. Chem. Soc. Rev. 2014, 43, 6239-6253. [CrossRef] 
21. Sun, D.; Luo, Z.; Lu, J.; Zhang, S.; Che, T.; Chen, Z.; Zhang, L. Electrochemical dual-aptamer-based biosensor for nonenzymatic detection of cardiac troponin I by nanohybrid electrocatalysts labeling combined with DNA nanotetrahedron structure. Biosens. Bioelectron. 2019, 134, 49-56. [CrossRef]

22. Huang, H.; Zhu, J.J. The electrochemical applications of rare earth-based nanomaterials. Analyst 2019, 144, 6789-6811. [CrossRef]

23. Eissa, S.; Zourob, M. Aptamer-based label-free electrochemical biosensor array for the detection of total and glycated hemoglobin in human whole blood. Sci. Rep. 2017, 7, 1016. [CrossRef]

24. Wu, M.-S.; Yuan, D.-J.; Xu, J.-J.; Chen, H.-Y. Sensitive electrochemiluminescence biosensor based on Au-ITO hybrid bipolar electrode amplification system for cell surface protein detection. Anal. Chem. 2013, 85, 11960-11965. [CrossRef]

25. Liu, Q.; Li, Y.; Zhang, L.; Li, D.; Fan, C.; Long, Y.-T. Comparative studies on electrocatalytic activities of chemically reduced graphene oxide and electrochemically reduced graphene oxide noncovalently functionalized with poly(methylene blue). Electroanalysis 2010, 22, 2862-2870. [CrossRef]

26. Li, M.; Guo, X.; Li, H.; Zuo, X.; Hao, R.; Song, H.; Aldalbahi, A.; Ge, Z.; Li, J.; Li, Q.; et al. Epitope binning assay using an electron transfer-modulated aptamer sensor. ACS Appl. Mater. Interfaces 2018, 10, 341-349. [CrossRef]

27. Campanella, L.; Tomassetti, M. The Applications of sensors and biosensors in investigating drugs, foods, and nutraceuticals. Sensors 2019, 19, 3395. [CrossRef]

28. Prabowo, B.; Purwidyantri, A.; Liu, K.-C. Surface plasmon resonance optical sensor: A Review on light source technology. Biosensors 2018, 8, 80. [CrossRef]

29. Zhao, Y.-W.; Wang, H.-X.; Jia, G.-C.; Li, Z. Application of aptamer-based biosensor for rapid detection of pathogenic Escherichia coli. Sensors 2018, 18, 2518. [CrossRef]

30. Ponzo, I.; Möller, F.M.; Daub, H.; Matscheko, N. A DNA-based biosensor assay for the kinetic characterization of ion-dependent aptamer folding and protein binding. Molecules 2019, 24, 2877. [CrossRef]

31. Liu, J.; Jasim, I.; Shen, Z.; Zhao, L.; Dweik, M.; Zhang, S.; Almasri, M. A microfluidic based biosensor for rapid detection of Salmonella in food products. PLoS ONE 2019, 14, e0216873. [CrossRef] [PubMed]

32. Zhbanov, A.; Yang, S. Electrochemical impedance spectroscopy of blood for sensitive detection of blood hematocrit, sedimentation and dielectric properties. Anal. Methods 2017, 9, 3302-3313. [CrossRef]

33. Yüce, M.; Ullah, N.; Budak, H. Trends in aptamer selection methods and applications. Analyst 2015, 140, 5379-5399. [CrossRef] [PubMed]

34. Lin, H.I.; Wu, C.C.; Yang, C.H.; Chang, K.W.; Lee, G.B.; Shiesh, S.C. Selection of aptamers specific for glycated hemoglobin and total hemoglobin using on-chip SELEX. Lab Chip 2015, 15, 486-494. [CrossRef]

35. Moon, J.M.; Kim, D.M.; Kim, M.H.; Han, J.Y.; Jung, D.K.; Shim, Y.B. A disposable amperometric dual-sensor for the detection of hemoglobin and glycated hemoglobin in a finger prick blood sample. Biosens. Bioelectron. 2017, 91, 128-135. [CrossRef]

36. Chen, Y.; Xiang, J.; Liu, B.; Chen, Z.; Zuo, X. Gold nanoparticle-engineered electrochemical aptamer biosensor for ultrasensitive detection of thrombin. Anal. Methods 2020, 12, 3729-3733. [CrossRef] 